\title{
IMPACT OF MYCO-INDUCED POSTHARVEST DETERIORATION ON THE PROXIMATE COMPOSITION OF ROOTS OF SWEETPOTATO (Ipomoea batatas [L] LAM) GROWN IN EBONYI STATE
}

\author{
E. A. Alum ${ }^{1}$, S.O. Umeh ${ }^{2}$, J.I. Reuben-Kalu ${ }^{1}$ and A. N. Ohuoba ${ }^{1}$ \\ ${ }^{I}$ National Root Crops Research Institute, Umudike, Abia State, Nigeria \\ ${ }^{2}$ Applied Microbiology and Brewing Department, Nnamdi Azikiwe University, Awka, Anambra \\ State, Nigeria. \\ Email:eucharianrcri@gmail.com
}

\begin{abstract}
Fungal pathogens have been indicted as important agents responsible for postharvest losses of either quantitative or qualitative terms. This study was aimed at investigating the impact of postharvest rot induced by morphologically and Partial Internal Transcribed Spacer rDNA Sequence characterized fungi- A. flavus, Penicillium expansum, A. awamori, A. niger, Rhizopus oryzae, Fusarium solani and Botrydiplodiae theobromae isolated from rotted sweetpotato roots on the proximate composition of sweetpotato roots. Using a Completely Randomized Design with two replications, samples of healthy roots and fungi-infected roots of two sweetpotato cultivars'Tupiaochi' and 'Oyorima' were analyzed for moisture, crude fibre, crude protein, ash, fat, carbohydrate and dry matter and the data were subjected to Analysis of Variance using SPSS and significant treatment means separated using Duncan's New Multiple Range Test. Results revealed the corresponding proximate values for the sweetpotato cultivars- Tupiaochi and Oyorima to be $75.25 \%$ and 70.50\%Moisture, 2.92 and 1.99\%Crude Fibre, 2.62 and 5.05\% Protein, 2.24 and 1.48\% Ash, 0.44 and 1.34\% Fat and 16.33 and 19.64\% Carbohydrates respectively. Findings from the fungi impact assessment revealed that fungal attack depletes important proximate components such as Carbohydrates, crude fibre and moisture while increasing crude protein, fat and ash of the roots, indicating that sweetpotato roots attacked by these test fungi beyond two weeks are unfit for consumption as they will be deficient of the major food nutrients they should have supplied to the body. Proper handling, storage and mitigation of fungal spoilage of sweetpotato roots will ensure the conservation of their nutritional components.
\end{abstract}

Key Words: Impact, Myco-induced, Proximate Composition, Postharvest Deterioration, Sweetpotato

https://dx.doi.org/10.4314/jafs.v17i1.7

\section{INTRODUCTION}

The quality of any crop depends on the level of nutritional content of such a crop (Markson et al., 2010b). For root and tubers; their value is in the quantity and quality of their nutritional Journal of the Faculty of Agriculture and Veterinary Medicine, Imo State University Owerri website: www ajol.info 
Journal of Agriculture and Food Sciences

Alum, E.A., Umeh S.O., Reuben-Kalu, J.I. \& Ohuoba A. N. ${ }^{90}$ Volume 17 Number 1, April 2019 pp $89-97$

content. Sweetpotato is a nutritionally rich crop in which are found various types of nutrients including antioxidants (phenolic acids, anthocyanins and carotenoids), vitamins, minerals, dietary fibre, proteins and non-fibrous carbohydrates (Woolfe, 1992). One way of its determination is via proximate analysis which is a system of analysis of nutrients in which the gross components (proteins, fat, carbohydrate, ash etcetera) of a food material are determined.

Moreover, the nutrient composition of food commodities has been established to affect the microflora and deterioration of the food crop. Microbial spoilage of sweetpotato and other foods is a metabolic process brought about by microbial action and causes food to become undesirable or unacceptable for human consumption due to deterioration in quality characteristics (rotting, discoloration and formation of off-flavors in the food products depending on the types of microorganisms and their corresponding physiological activities).

Microbial spoilage of sweetpotato is associated with decrease in starch, total sugar, organic acid (ascorbic and oxalic acid) contents with concomitant increase in polyphenols and ethylene. Adeogun et. al (2014) investigated healthy and diseased white yams tubers (Dioscorea rotundata) from different open markets in Lagos State in a proximate analysis and revealed gradual reduction in ash, lipid and crude fibre contents in the diseased yam tubers with reference to healthy yam except protein and moisture that had an insignificant increase in the diseased yam. The significance difference ( $\mathrm{P} \unlhd \mathbf{\$} 0.05)$ between the healthy and diseased in the nutritional composition of the yam was expressed in carbohydrate, moisture and fibre contents of the yam while there was no significance difference in protein, ash and fat contents in the nutritional status of healthy and infected yam. Sanyaolu et al. (2014) carried out investigation and reported on the proximate composition of post-harvest mycodeterioration of Irvingia gabonensis seeds.

The impact of fungi infection on the varieties of sweetpotato grown by the farmers in Ebonyi state has not been documented before now. This study therefore aimed at analyzing healthy and fungi infected roots of two sweetpotato cultivars from Ebonyi state for proximate components including moisture, dry matter, crude fibre, fat, ash, protein and carbohydrate with a view to determining the effect of fungi rot on the root nutrient composition.

\section{MATERIALS AND METHODS}

\section{Pathogen inoculums}

Seven species of sweetpotato rot-associated fungi (A. flavus, Penicillium spp, A. awamori, A. niger, Rhizopus oryzae, Fusarium solani and Botrydiplodiae theobromae) isolated from diseased sweetpotato from Ebonyi state, identified morphologically and via Partial ITS rDNA Sequence analysis and confirmed pathogenic in a previous study were employed in the study. 
Journal of Agriculture and Food Sciences Alum, E.A., Umeh S.O., Reuben-Kalu, J.I. \& Ohuoba A. N. Volume 17 Number 1, April 2019 pp $\quad 89-97$

\section{Sweetpotato samples}

Healthy sweetpotato root samples (two sweetpotato cultivars -'Tupiaochi' and 'Oyorima' commonly grown in Ebonyi state) were collected from Ebonyi sweetpotato farmers into cellophane bags, properly labeled and taken to NRCRI Plant Pathology Laboratory for analysis.

\section{Pathogenicity}

To produce infected roots, the method of Adeogun et. al (2014) was adopted. Some visually healthy roots of sweetpotato were washed with tap water and rinsed with distilled water. The roots were surface sterilized with $70 \%$ ethanol, after which cylindrical discs were removed from the roots using a sterile $4 \mathrm{~mm}$ cork borer. Using another cork borer of $4 \mathrm{~mm}$ diameter, a disc of a five-day old pure culture of each test isolates was inoculated into the hole created in the roots. This was followed by careful replacement of the parts of the tissue bore out and then sealing the area with sterile vaseline and labeling accordingly. The inoculated roots were placed in clean polyethylene bag (one root per bag) each moistened with wet balls of absorbent cotton wool to create a humid environment and incubated for 2 weeks at room temperature $\left(28 \pm 2^{\circ} \mathrm{C}\right)$. Healthy un-inoculated root samples were also stored at ambient condition for two weeks, after which they remained healthy. After the two weeks of incubation, the roots inoculated with fungi were observed to be infected and rotted and a re-isolation of the test fungi was successfully made from the infected roots.

\section{Moisture content}

This involves measurement of the weight loss due to the evaporation of water and was determined using the methods of Chinedu and Nwinyi (2012) with modification. Roots were peeled, wiped and chopped into small pieces. Empty crucibles were washed, dried in oven, cooled in the desiccators and the weight of each crucible taken. Twenty grams of the undried sample were weighed into the pre-labeled sterile crucible of constant weight and the crucible with the sample placed in an oven set at $80^{\circ} \mathrm{C}$ for $2 \mathrm{hr}$. This was removed and cooled in desiccators. After drying, using a measuring analytical balance, the weights were measured every one hour until a constant weight was obtained.

The loss in weight was taken as the moisture content and calculated thus:

$$
\text { Moisture Content }=\frac{\text { Loss in weight }\left(W_{2}-W_{3}\right)(g)}{\text { Original weight of sampleg }\left(W_{2}-W_{1}\right)} \times 100
$$

Where:

$\mathrm{W}_{1}=$ initial weight of empty crucible,

$\mathrm{W}_{2}=$ weight of crucible + food before drying,

$\mathrm{W}_{3}=$ final weight of crucible + food after drying. 
Journal of Agriculture and Food Sciences

Alum, E.A., Umeh S.O., Reuben-Kalu, J.I. \& Ohuoba A. N.92 Volume 17 Number 1, April 2019 pp

\section{Dry matter Determination}

Dry matter content (\%) was calculated by 100 - Moisture content (\%).

\section{Ash content determination}

The ash of a foodstuff is the inorganic component (minerals) of the sample after all moisture has been removed as well as the organic material burnt away. The method of AOAC (2000) was used in determining the ash content.

Three grams (3g) of the sample was weighed into a crucible of known weight and placed in a furnace which was ignited for about 24 hours until grey ash was obtained. The crucible containing the ash sample was removed from the furnace and cooled in the dessicator and then weighed using the analytical balance.

$$
\% \mathbf{A s h}=\frac{\text { weight of ash }}{\text { weight of sample g }} \times 100
$$

Protein Content: Protein content was determined in the form of Total nitrogen using the AOAC (2000).

Fat content determination: The acid hydrolysis method of A.O.A.C. (2000) was used to determine the fat content. Eight grams $(8 \mathrm{~g})$ of samples were weighed in duplicate and digested in acid and the digests transferred to flasks where the fat was extracted with ethers. The ether extract was transferred into previously dried and weighed flasks and the ethers evaporated. The remaining fat was dried and weighed and determination made for the $\%$ fat calculated.

Crude fibre: The method of the AOAC (2000) was adopted in determination of crude fibre content of the samples.

Carbohydrate content determination: The method of AOAC (2000) was used to determine the Carbohydrate content; which was done by subtracting the sum of total crude fibre, total fat content, total protein, ash and moisture from 100.

$\%$ Carbohydrate $=100-(\%$ protein $+\%$ fat $+\%$ fibre $+\%$ ash $+\%$ moisture $)$

Data analysis: Data were subjected to Analysis of Variance (ANOVA) using SPSS and significant treatment means separated using Ducan's New Multiple Range Test.

\section{RESULTS AND DISCUSSION}

The results of proximate compositions of the healthy roots are presented in Figure 1. The moisture content of both sweetpotato cultivars was high (75.25\% for 'Tupiaochi' and $70.50 \%$ for 'Oyorima'). According to Rees et al (2003), high water content of Sweetpotato makes storage difficult and the sweet potato roots vulnerable to microbial attacks, resulting in high losses. The high percentage moisture content of the screened roots was indicative of poor shelf life Journal of the Faculty of Agriculture and Veterinary Medicine, Imo State University Owerri website: www ajol.info 
characteristics and high chances of being attacked by microbes. The crude fibre content of both sweetpotato cultivars was 2.92 for 'Tupiaochi' and $1.99 \%$ for 'Oyorima'. Results on values of crude fibre recorded for both sweetpotato varieties can be said to be low and agrees with data $((0.65 \pm 0.03 \%)$ for TIS/87/0087 (fresh wet basis) by Eleazu and Ironua (2014). The protein content of 'Oyorima' was $5.05 \%$ and significantly higher than that recorded by 'Tupiaochi' cultivar $(2.24 \%)$. This supports report that sweetpotatoes contain unique proteins called sporamins that account for more than $80 \%$ of the total proteins. Protein is required for proper body building and replenishment of warm out tissue in human beings. The values obtained for protein in 'Oyorima' cultivar is comparable with the data reported by Ukom et al. (2009) for TIS 87/0087 sweetpotato cultivar, a value that was significantly higher than those the authors reported for other sweetpotato cultivars (CIP-Tanzania, Ex-Igbariam and TIS 8164 with mean protein value of $3.28 \pm 0.04,4.16 \pm 0.85$ and $3.94 \pm 0.03$ respectively).

The importance of lipids in food substances cannot be over-emphasized as it contributes significantly to the energy value of foods and also promotes the absorption of fat soluble vitamins (Atasie et al., 2009). The assay of the lipid content of the flour showed that it had low total lipid content (1.44 and 1.34\% respectively for 'Tupiaochi' and 'Oyorima') and this could be of benefit to those that suffer from atherosclerosis or related problems. The ash content varied from $1.48 \%$ for 'Oyorima' to $2.42 \%$ for 'Tupiaochi'. The carbohydrate content was moderately high in the two cultivars (16.33 and $19.64 \%$ respectively for 'Tupiaochi' and 'Oyorima'). The high carbohydrate content of the sweetpotato cultivars could make them good sources of energy as well as substrates for the production of aromatic amino acids and phenolic compounds through the Shikimic acid pathway.

From the foregoing, the nutritional attributes of healthy sweetpotato cultivars grown in Ebonyi state can be praised; having proximate components with potential nutritional and health benefits, which if continually available in the roots should enable the sweetpotatoes to contribute significantly to a healthy and balanced diet in Ebonyi state and beyond.

Table 1 presents a comparative result of the percentage Proximate Composition of flour from Diseased and healthy roots of Ipomae batatas. A one-way ANOVA conducted to compare the means of the proximate composition of healthy and fungi rotted roots of the sweetpotato cultivars (Table 1) showed significant differences $(\mathrm{P}=0.05)$ among the treatment groups (healthy and fungi rotted roots of both tested sweetpotato cultivars) in moisture content, crude fibre, crude protein, ash, fat and carbohydrate contents. There was a statistically significant reduction in the moisture, crude fibre and carbohydrate content and statistically different increase in the crude protein, ash and fat contents of the artificially phytopathogen inoculated/ infected roots irrespective of cultivar, vis avis the healthy roots. The rate of variation between these parameters was dependent on the infecting pathogens and the sweetpotato cultivar.

Proximate analysis of the two sweetpotato cultivars showed significant reduction $(p=0.05)$ in the amount of moisture, crude fibre and carbohydrate in the fungi infected/rotted roots when compared to the healthy and control roots of both varieties. The significant decrease in crude Journal of the Faculty of Agriculture and Veterinary Medicine, Imo State University Owerri website: www ajol.info 
Journal of Agriculture and Food Sciences

Alum, E.A., Umeh S.O., Reuben-Kalu, J.I. \& Ohuoba A. N. Volume 17 Number 1, April 2019 pp $89-97$

fibre recorded in the present study is in agreement with the finding by Adeogun et al. (2014). In their studies titled "Studies on Fungi Isolated from Dioscorea Rotundata (Yam) collected from Open Markets in Lagos Nigeria", the authors reported a gradual reduction in crude fibre of diseased yam tubers with reference to healthy yam. Losses are in the form of reduction in the quality of the tubers through breakdown of tissues resulting in anatomical aberrations and depletion of the nutrient component such as protein, lipids and the major one - starch (Markson et al., 2010a; Arinze, 2005).

The observed general significant decrease in the moisture, carbohydrate and crude fibre contents of the roots infected with fungal pathogens when compared with that of healthy roots samples may be attributed to the fact that the fungi utilize the water and carbohydrate for metabolic activities (Burnett, 1976) and growth. Also according to Doyle (2007), microbial spoilage of sweetpotato is found associated with decrease in starch, total sugar, organic acid (ascorbic and oxalic acid) contents with concomitant increase in polyphenols and ethylene.

On the contrary, the crude protein, ash content and fat contents of the fungi infected sweetpotato cultivars were shown by the analysis of variance to exhibit significant increase $(p<0.05)$ when compared to the healthy and control roots of both varieties. This corroborates report by Rodolfo et al. (2000) that fungi increase the protein content of samples on which they grow. The increase in the fat content of fungi infected roots from that of the healthy roots is in keeping with reports by Sanyaolu et al. (2014) that there was significant increase in the fat content in diseased Irvingia gabonensis.

\section{CONCLUSION}

The effect of the activities of these pathogens on sweetpotato is of concern because it has shown that sweetpotato roots attacked by these test fungi beyond two weeks are not fit for consumption as they will no longer supply the major food nutrients they should have provided to the body. Farmers and handlers of sweetpotato should realize that a crop well produced and less protected is a crop lost and should take a more serious look at maintaining the quality of their harvested produce. Adequate and proper care and handling of the roots and mitigation of fungal spoilage of the roots at postharvest are critical and will ensure the conservation of these nutritional components. 

Volume 17 Number 1, April 2019 pp $\quad 89$-.97

\section{REFERENCES}

Adeogun, O. O., Adekunle, A. A., Samuel, O. T. and Ebabhi, A. M. (2014). Studies On Fungi Isolated From Dioscorea Rotundata (Yam) Collected From Open Markets In Lagos Nigeria.International Journal of Phytopathology,03 (03): 139-147.

Akindumila, F. and Glatz, B.A. (1998). Growth and oil production of Apiotrichum curvatum in tomato juice. Journal of Food Products.61(11): 1515- 1517.

Amadioha, A. C. (2001). Changes in the biochemical composition of stored potato tubers during pathogenesis of Rhizoctonia bataticola. Arch. Phytopath Pflanz. 34: 45 - 54.

Arinze, A.E. (2005). Plant Pathology and Post -harvest Food Loss. An inaugural lecture series No. 43 P.29-72.

Association of Official Analytical Chemists (A.O.A.C.) (2000). Official Methods of Analysis. 17th ed. Association of Official Analytical Chemists, Washington, DC.

Atasie, V.N., T.F. Akinhanmi and C.C. Ojiodu. 2009. Proximate Analysis and Physico Chemical Properties of Groundnut (Arachis hypogaea L.). Pakistan Journal of Nutrition. 8(2): 194197.

Burnett, J.H. (1976). Fundamentals of Mycology. 2nd edition. Edward Arnold Publishers, Ltd. canada. 673pp.

Doyle, M.E. (2007). Microbial Food Spoilage - Losses and Control Strategies. FRI BRIEFINGS, Food Research Institute, University of Wisconsin-Madison.

http://fri.wisc.edu/docs/pdf/FRI_Brief_Microbial_Food_Spoilage_7_07.pdf

Eleazu, C. O. and Ironua, C. (2014). Physicochemical composition and antioxidant properties of a sweetpotato variety (Ipomoea batatas L) commercially sold in South Eastern Nigeria African Journal of Biotechnology, 12(7), pp. 720-727.

Markson, A. A., Amadioha, A. C., Wokocha, R. C., Omosun, G. and Madunagu, B. E. (2010a) Biochemical Alteration of Yam Tuber Tissues Incited by Botryodiplodia theobromae Pat. International Journal of Current Research, 4: 94-97.

Markson, A. A., Omosun, G., Madunagu, B. E., Amadioha, A. C.,Wokocha, R. (2010b). Physicochemical Alteration of Tissues of White Yam (Dioscorea rotundata Poir) Tubers Incited by Botryoiplodia theobromae Pat. International Journal of Current Research, 4: 55-61.

Rees, D., van Oirschot., Q.E.A. and Amour, R.(2003). Cultivar variation in keeping quality of sweet potatoes.Postharvest Biology and Technology, 28(2):313

Rodolfo, A.D., Teresa, M.A., Valdez, S.J. and Mariano, C.M. (2000). Feeding value of proteinenriched sweet potato for Broilers. Research Abstracts 
Sanyaolu, A. A., Adekunle, A. A. and Osuntoki, A. (2014). The Effects of Post-harvest Mycodeterioration on the Proximate Composition of Irvingia gabonensis seeds, International Journal of Phytopathology. 3(1): 41-48.

Scot, N. (2009). Rhizopus Soft Rot of Sweetpotato. Plant Disease PD 68<http://www.ctahr.hawa ii.edu/freepubs.semitectum in Florida. Plant Diseases 78: 926.

Ukom, A.N., Ojimelukwe P.C. and Okpara D.A. (2009). Nutrient Composition of Selected Sweet Potato [Ipomea batatas (L) Lam] Varieties as Influenced by Different Levels of Nitrogen Fertilizer Application. Pakistan Journal of Nutrition 8 (11): 1791-1795.

Woolfe, J. A. (1992). Sweetpotato: An untapped food resource. Cambridge University Press. 


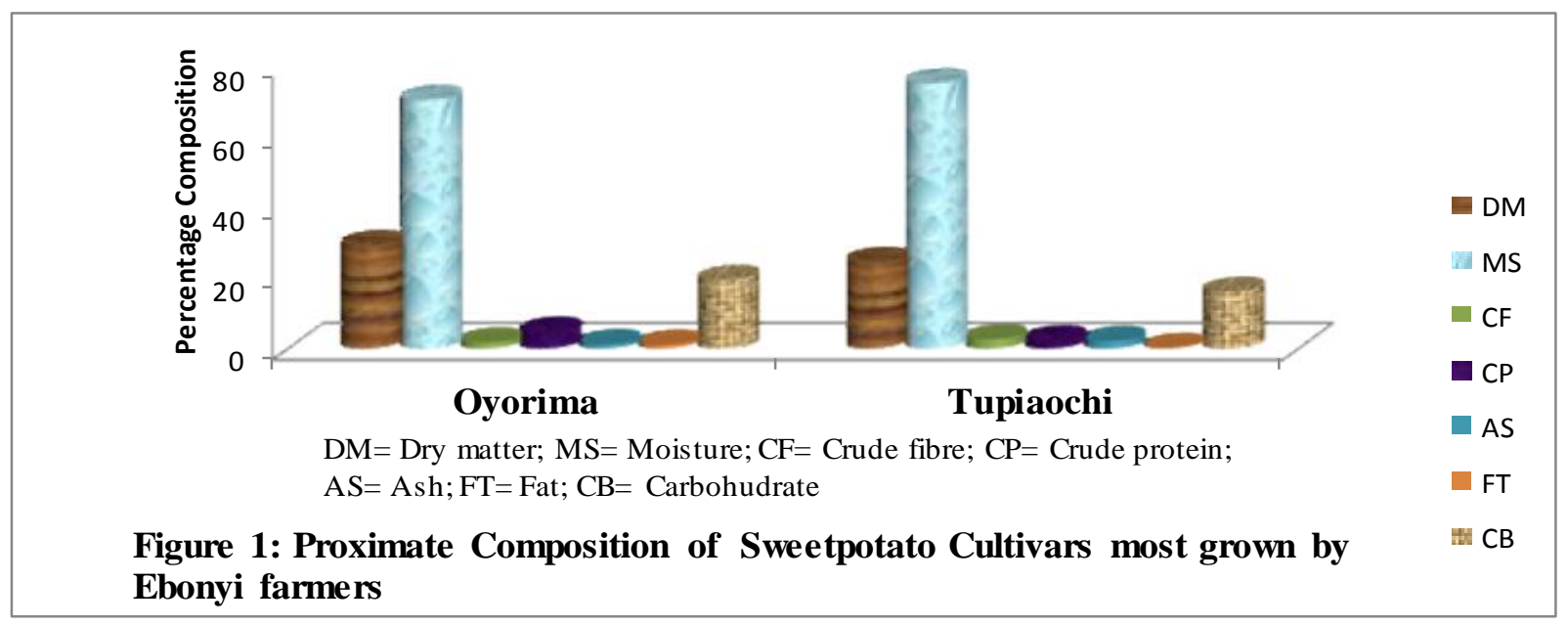

Table 1: A Comparative Percentage Proximate Composition of flour from Diseased and Healthy Roots of Ipomae batatas

\begin{tabular}{|c|c|c|c|c|c|c|c|c|}
\hline \multicolumn{9}{|c|}{ PROXIMATE COMPOSTION } \\
\hline \multirow{9}{*}{ TUPIAOCHI } & & & M & $\mathrm{CF}$ & $\mathrm{P}$ & A & $\mathrm{F}$ & CARB \\
\hline & $\begin{array}{l}\text { Healthy } \\
\text { root }\end{array}$ & Control & $75.2500_{\mathrm{e}}$ & $2.9400_{\mathrm{e}}$ & $2.6200_{\mathrm{a}}$ & $2.4200_{\mathrm{a}}$ & $0.44 a$ & $16.3300_{d}$ \\
\hline & Diseased & Ro & $72.9250_{\mathrm{c}}$ & $2.2850_{\mathrm{a}}$ & $4.2800_{\mathrm{d}}$ & $3.9450_{\mathrm{d}}$ & $2.3800_{c}$ & $14.1850_{\mathrm{a}}$ \\
\hline & root & $\mathrm{Bt}$ & $71.8200_{a}$ & $2.3100_{\mathrm{b}}$ & $4.6200_{\mathrm{f}}$ & $4.4600 \mathrm{f}$ & $2.3250_{c}$ & $14.4650_{\mathrm{a}}$ \\
\hline & & Fs & $72.9950_{c}$ & $2.4050_{\mathrm{c}}$ & $4.2100_{c}$ & $3.8500 \mathrm{c}$ & $1.2800_{\mathrm{b}}$ & $15.2600_{c}$ \\
\hline & & An & $71.9600_{b}$ & $2.2500_{\mathrm{a}}$ & $4.4350_{\mathrm{e}}$ & $4.1050 \mathrm{e}$ & $2.8200_{c}$ & $14.4300_{\mathrm{a}}$ \\
\hline & & Af & $73.3450_{\mathrm{d}}$ & $2.4400_{\mathrm{c}}$ & $4.2350_{\mathrm{c}}$ & $3.8300_{\mathrm{c}}$ & $1.2450_{\mathrm{b}}$ & $14.9050_{\mathrm{b}}$ \\
\hline & & Ps & $73.0150_{\mathrm{c}}$ & $2.8550_{\mathrm{d}}$ & $4.0650_{\mathrm{b}}$ & $3.4350_{\mathrm{b}}$ & $1.1300_{\mathrm{b}}$ & $15.5000_{\mathrm{c}}$ \\
\hline & & Aa & $73.0050_{c}$ & $2.8350_{\mathrm{d}}$ & $4.2250_{c}$ & $3.4500_{\mathrm{b}}$ & $1.1000_{\mathrm{b}}$ & $15.4850_{\mathrm{b}}$ \\
\hline \multirow[t]{8}{*}{ OYORIMA } & $\begin{array}{l}\text { Healthy } \\
\text { root }\end{array}$ & Control & $70.5000_{a}$ & $1.9900_{\mathrm{a}}$ & $5.0500_{c}$ & $1.4800_{\mathrm{d}}$ & $1.3400 \mathrm{~g}$ & $19.6400_{\mathrm{a}}$ \\
\hline & Diseased & $\mathrm{Bt}$ & $67.4100_{\mathrm{e}}$ & $1.3300_{\mathrm{d}}$ & $6.1150_{b}$ & $3.1850_{\mathrm{a}}$ & $3.9200_{c}$ & $18.0400_{\mathrm{c}}$ \\
\hline & root & Ro & $67.9000_{d}$ & $1.1950_{\mathrm{f}}$ & $6.3450_{a}$ & $3.2000_{\mathrm{a}}$ & $3.9750_{\mathrm{b}}$ & $17.3850_{\mathrm{c}}$ \\
\hline & & Fs & $68.4100_{b}$ & $1.3500_{\mathrm{d}}$ & $6.0600_{\mathrm{b}}$ & $3.0900_{\mathrm{b}}$ & $2.3250_{\mathrm{d}}$ & $18.8450_{\mathrm{b}}$ \\
\hline & & An & $67.8000_{\mathrm{d}}$ & $1.2950_{\mathrm{e}}$ & $6.2650_{a}$ & $3.1800_{\mathrm{a}}$ & $4.0650_{\mathrm{a}}$ & $17.3950_{\mathrm{c}}$ \\
\hline & & Af & $68.6500_{b}$ & $1.6050_{\mathrm{c}}$ & $6.0450_{b}$ & $2.9700_{\mathrm{d}}$ & $1.8250_{\mathrm{f}}$ & $18.9050_{\mathrm{b}}$ \\
\hline & & Ps & $68.4550_{\mathrm{b}}$ & $1.6400_{\mathrm{b}}$ & $6.0800_{\mathrm{b}}$ & $3.0800_{\mathrm{c}}$ & $1.8950_{\mathrm{e}}$ & $18.8500_{\mathrm{b}}$ \\
\hline & & $\mathrm{Aa}$ & $68.4100_{\mathrm{b}}$ & $1.6650_{\mathrm{b}}$ & $6.0550_{\mathrm{b}}$ & $3.1050_{\mathrm{c}}$ & $1.9200_{\mathrm{e}}$ & $18.9800_{\mathrm{b}}$ \\
\hline
\end{tabular}

Values are means of two replicates. Mean values with different subscripts along the column are significantly different at $\mathrm{P}=0.05$.

$\mathrm{Bt}=$ B. theobromae $; \mathrm{Ro}=R$. oryzae $; \mathrm{Fs}=\mathrm{F}$ solani; $\mathrm{An}=$ A. niger $; \mathrm{Af}=A$. flavus $; \mathrm{Aa}=A$. awamori $;$ $\mathrm{Ps}=$ Penicillium $p$; $\mathrm{M}=$ Moisture; $\mathrm{A}=\mathrm{Ash} ; \mathrm{CF}=$ Crude fibre; $\mathrm{F}=\mathrm{Fat} ; \mathrm{P}=$ Protein;

$\mathrm{Cab}=$ Carbohydrate. 